\title{
Analysis on the Application of Four Resources Models in College English
}

\author{
Hongxia Dai \\ Nanchang institute of Science and Technology \\ Nanchang, China
}

\author{
Zhongmeng Chen \\ Nanchang Normal University \\ Nanchang, China
}

\begin{abstract}
Freebody and Luke first proposed the four resources models, which regarded language as a resource and are mainly used in the practical teaching of second language. They are used in various language learning situations by many teachers to improve students' language learning participation, enthusiasm and criticism. The application of the four resources models cannot be the same or copied. Otherwise the form is greater than the effect. This article is based on the college students' class B (the college entrance examination English scores between 105-119) of the two freshmen class. Four resources patterns was attempted by authors to apply four resources patterns in university public English teaching for the first time, then analyzed the feedback, and reveal many problems that exist in the implementation process of four resources models in order to further revised four resources models provide reference for the practical application in college English teaching.
\end{abstract}

Keywords-four resources models; college English Teaching; Feedback; experience

\section{INTRODUCTION}

The four resources models [1] were proposed by Freebody and Luke. They believe that there are four kinds of identity changes in the process of learning texts. Then, it changes to the meaning maker (use background knowledge to understand the main idea of the article, understand the extended meaning of the language, the author's intention, etc.). After transitioning to text user (using new words and sentences in the text to write dialogues, etc.), the critics of text critic mainly propose their own views on the thoughts in the text and communicate with classmates finally. This teaching model was originally developed in the context of the acquisition of the Australian mother tongue. In the second language teaching situation in the mother tongue environment, four resources models can be implemented according to special situations, such as in the teaching process of college English. Students with a certain English foundation can make flexible use of their existing knowledge of language and grammar, take students as the leading role, supplemented by teachers' proper explanation, and make full use of the idiomatic words, sentences and texts in the text to improve the fixed pattern of students' structure of chinglish. Second, on the basis of full reading the text language symbols, students can effectively grasp the author's thoughts in English texts, conduct cross-cultural criticism, and enhance their ability to think independently and communicate cooperatively. Third, we should establish an unimpeded communication feedback mechanism between teachers,

University-level project of Nanchang normal university: JGKT-16-24: A study on the application of "resources models" in college public English teaching students and students, so as to effectively improve the practical utility of the four resources models.

\section{LITERATURE REVIEW}

College public English (college English or public English for short) is a necessary course for college students majoring in non-English. However, due to the inconsistency of their English foundation, some universities have implemented stratified or graded teaching. According to students' English scores in the college entrance examination, targeted teaching based on students and language has been established, and certain learning effects have been achieved [2][3].However, compared with English majors, the position of marginalization of college public English has not changed in various universities, and the tendency of English "instrumentalization" was becoming more and more serious. Most front-line college English teachers are inclined to improve teaching methods or incorporate new contents, such as the application of Mooc [4], the combination of video online teaching [5]; The transmission of culture [6], or introduced new teaching concepts, such as the application of metacognitive theory [7], the guidance of structuralism [8] and so on. These indicate that college English teachers are trying hard to find the teaching methods and ways that are more suitable for their students. But browsing their plans, only to find a few more obvious defects. It prefers subjectivity, the teaching effect of thought often are took it for granted .It was thought students subjectively need some new teaching modes, and the teaching object aren't be clearly understood. Namely, they often see it from the perspective of teachers, rather than through the survey of students or feedback in the analysis and the process of gradual improvement. Therefore, all kinds of new college English teaching methods or models lack of the testing mechanism of teaching methods. They are just refurbished the teaching modes without sufficient evidences (such as students' opinions or tests) to explain the teaching effect. In view of this kind of malpractice in college English teaching innovation, this paper mainly believes that the teaching modes of college English should be mainly based on students' acceptance and teaching effect. Secondly, we should make full use of the successful examples of the four resources models and make effective improvement on the basis of this. Therefore, it is necessary to make a brief summary of the four resources models used by predecessors.

The application of the four resources models in language teaching has experienced two main stages: one is the 
experimental period (from the end of the 20th century to the beginning of the 21 st century, it is mainly an experimental course of language teaching initiated by Freebody and Luke et al., in foreign countries; and the dialogue on the supplement of the four resources models [9]; and the meaning construction of Chinese classroom in junior high school [10]. Four resources models were used as the map of teaching practice [11] and the application of four resources models in curriculum design and so on. Second, during the maturity and extension period (the decade of the 21 st century), various forms of deformation application and reflection of the four resources models are applied and reflected. Through the four resources models, the family-school cooperation in the community is viewed. Four resources models are designed and applied in reading and writing education. The extension and application of four resources models in comics. The application of four resources models in the planning and design of reading and writing courses and so on. It can be seen that the four resources models have been widely used in foreign countries, including macro cultural discourse and micro classroom teaching practice. However, in China, the application of the four resources models in language teaching started late and involved limited teaching objects, which were mainly used in English teaching in English majors. In China, only a few researchers have applied this model in intensive reading teaching in English majors [12]. This model has been not applied in the teaching of college public English. On the basis of studying the practice of Bingfei liu, in combination with one of normal college in 2016 in Nanchang on the implementation of layered teaching practice. Four teaching resources models were tried in class B9, class B10 (two freshman class), and were summarized the implementation process of feedback, in order to better expand four resources models in college English teaching.

\section{IMPLEMENTATION PROCESS}

On the basis of full considering the English knowledge structure of Chinese students, teachers should actively help students when implementing the four resources models, not just a spectator. Teachers playing different roles in different stages so that students can get into the state of self-study well. In the process of implementation, teachers should also observe the response of students to see whether students are engaged in learning the assigned teaching tasks and adjust the teaching steps at different times. After a period of time, such as, a week later, I will randomly pick out a few students to communicate, ask them for their opinions and make timely corrections. After a semester or an academic year, I collect opinion CARDS in the class group, solicit students' opinions extensively, and get better feedback from students. The process was shown in fig. 1 .

\begin{tabular}{|c|l|l|l|l|}
\hline $\begin{array}{c}\text { Class } \\
\text { assign } \\
\text { ment }\end{array}$ & $\begin{array}{c}\text { Teaching } \\
\text { steps }\end{array}$ & \multicolumn{1}{|c|}{ Teacher's activities } & \multicolumn{1}{|c|}{$\begin{array}{c}\text { Students' } \\
\text { activities }\end{array}$} & \multicolumn{1}{|c|}{ The roles played } \\
\hline 0 & preview & $\begin{array}{l}\text { 1.assign task ;read } \\
\text { through the text; mark } \\
\text { the difficult points; look } \\
\text { up new words.2.full } \\
\text { prepare the class }\end{array}$ & $\begin{array}{l}\text { With the aid of } \\
\text { dictionaries or } \\
\text { other ways, } \\
\text { individuals read } \\
\text { and understand } \\
\text { the text }\end{array}$ & $\begin{array}{l}\text { Teacher: man assigned. } \\
\text { Students: text decoder } \\
\text { (individual) }\end{array}$ \\
\hline $\begin{array}{c}\text { class1, } \\
2\end{array}$ & $\begin{array}{c}\text { Introduction } \\
\text { Check the students' } \\
\text { preview and explain } \\
\text { the difficult points. }\end{array}$ & $\begin{array}{l}\text { Ask questions, } \\
\text { discuss and } \\
\text { record difficult } \\
\text { points in the text }\end{array}$ & $\begin{array}{l}\text { Teacher: supervisor and } \\
\text { decoder } \\
\text { Students: text decoder } \\
\text { and meaning maker }\end{array}$ \\
\hline 4 & $\begin{array}{c}\text { Text } \\
\text { comprehensi } \\
\text { on }\end{array}$ & $\begin{array}{l}\text { 1.re-assign the reading } \\
\text { task } \\
\text { 2.collect the students' } \\
\text { understanding and have } \\
\text { a discussion }\end{array}$ & $\begin{array}{l}\text { Read the text } \\
\text { carefully again } \\
\text { and record your } \\
\text { own } \\
\text { comprehension } \\
\text { after reading and } \\
\text { discuss with your } \\
\text { neighbors }\end{array}$ & $\begin{array}{l}\text { Teacher: task setters and } \\
\text { class organizers. } \\
\text { Students: meaning } \\
\text { builder and text user } \\
\text { (jointly) }\end{array}$ \\
\hline
\end{tabular}




\begin{tabular}{|c|c|c|c|c|}
\hline \multicolumn{5}{|c|}{ Cont. to Fig. 1} \\
\hline $\begin{array}{c}\text { class } 5, \\
6\end{array}$ & $\begin{array}{c}\text { Text } \\
\text { appreciation }\end{array}$ & $\begin{array}{l}\text { 1. Classify students by } \\
\text { understanding and } \\
\text { grouping them by } \\
\text { category } \\
\text { 2.Put forward the } \\
\text { perspective and guide } \\
\text { the students }\end{array}$ & $\begin{array}{l}\text { After } \\
\text { reorganizing, } \\
\text { discuss, record } \\
\text { group views, and } \\
\text { select group } \\
\text { representatives }\end{array}$ & $\begin{array}{l}\text { Teacher: organizer and } \\
\text { guide } \\
\text { Students: text user and } \\
\text { text critic (personal and } \\
\text { common) }\end{array}$ \\
\hline $\begin{array}{c}\text { class } 7 \\
8\end{array}$ & $\begin{array}{c}\text { Text } \\
\text { summary }\end{array}$ & $\begin{array}{l}\text { 1. Organize students to } \\
\text { speak, ask questions } \\
\text { and give score } \\
\text { 2. Collect group } \\
\text { presentations and } \\
\text { ratings, self- } \\
\text { evaluation }\end{array}$ & $\begin{array}{l}\text { Group } \\
\text { representatives } \\
\text { take turns to } \\
\text { speak (blackboard } \\
\text { writing or } \\
\text { showing PPT), } \\
\text { students ask } \\
\text { questions, present } \\
\text { their answers, and } \\
\text { the questioners } \\
\text { give scores }\end{array}$ & $\begin{array}{l}\text { Teacher: organizer, } \\
\text { manager and assignment } \\
\text { person } \\
\text { Student: textual criticism } \\
\text { (personal and mutual) }\end{array}$ \\
\hline
\end{tabular}

Fig. 1. Implementation process.

\section{CONCLUSION: FEEDBACK ANALYSIS}

Four resources models at level 16 B9, B10 class (English college entrance examination score from 100 to 110 ) were carried out a week. Through the observation, student's enthusiasm was very high because they are freshman. They were too willing to accept this new way of teaching; but at the time of group participation, their feeling was blank, they didn't know how to communicate topic and didn't have effective dialogues. The pattern of Chinese students' passive acceptance of knowledge has not changed overnight. Their participation is passive. Another reason is that the students' English foundation are not the same. Their comprehension of the text still depends on the teacher's explanation, so it is difficult to think and criticize the text effectively.

After one academic year (2016-2017), four kinds of resources teaching opinion CARDS were developed to test students' learning status, so as to collect students' feedback. The following attachment (Fig. 2) is a template for a student's opinion card. Only 25 students have submitted their opinion CARDS. Among the collected opinion CARDS, $76 \%$ of students have some difficulties in reflecting the follow-up of grammar. This shows that students' grammar knowledge is relatively weak in high school, and the comprehension of the text needs the guidance of teachers. However, students' enthusiasm for asking questions in class is not high. Sixty-two percent of the students said that they could understand what the students were saying on the stage, and that there was a certain basis for listening. Fifty percent of the students think that getting students to speak on the stage will improve their oral English. For this new form of teaching, acceptance is still not high, the effect is not obvious. The main reasons are as follows: first, freshmen do not develop the habit of self-study, and still stay in the teaching mode of teachers in high school. Secondly, the oral English practice in high school is very little, and it is in the exam-oriented teaching state and cannot adapt to the oral practice mode. Third, most of their classmates are not good at grammar. Based on the above three points, college English teaching should gradually transit from the traditional teacherled classroom teaching mode to four resources models. First, teachers should act as the decoder of text, so as to help students understand the grammar and vocabulary of text. Secondly, the teacher act as the meaning builder and text user of the demonstration, and guide the students to make a comparison. Finally, the critics of the text should also be teachers first, demonstrate well and provide several critical perspectives for students to think about problems. In a word, the classroom can only be handed over to the students if the students are more proficient and have a high degree of participation. Otherwise, the implementation of the four resources models cannot mobilize the students' enthusiasm and achieve the ideal learning effect. By extension, the implementation of the four resources models in any English teaching class should take into account the acceptance of students and make students gradually accept this teaching model. This transition period is more suitable for Chinese students' English teaching. 


\section{Personal information:}

1. Personal interests and hobbies: painting, listening to songs, watching movies, dancing, doing crafts and reading books.

2. Major: education for primary school.

3. Gender: female

4. Score of English college entrance examination: 106

\section{Question information:}

Question1. Which aspect do you think is difficult to follow in class? It's hard to keep up with learning grammar and sentence patterns.

Question2. Can you understand your classmates' English on the platform? Generally speaking, I can understand if the speed is moderate, pronunciation is standard.

\section{Suggestion:}

Question 1: Do you think what kind of teaching method need to be improved in classes?

I hope I can have an in-depth study of the new words and phrases before learning the text.

Question 2: Do you think speaking English on the platform will improve your oral English? What's your suggestion?

I think speaking English on stage can improve my oral English. I suggest teachers can recommend more books or APPS to improve our oral English for us to learn.

Fig. 2. Four resources teaching opinion CARDS.

\section{REFERENCES}

[1] Freebody P, Luke a. Literacies designed: Debates and Demands in Cultural Context [J]. Journal of Prospect, 1990, 5 (3).

[2] Xiufen Zheng. Practice and thinking of graded teaching of college English [J]. China higher education research, 2008 (12). (In Chinese).

[3] Luni Zhang. Empirical research on the effectiveness of college English experimental teaching [J]. Laboratory research and exploration, 2016 (2). (In Chinese).

[4] Leilei Wang. College public English teaching in the context of Moocs [J]. Journal of Yancheng Normal university, 2015 (05). (In Chinese).

[5] Jiao Wang . Application of video in college English teaching [J]. Journal of Hunan university of science and technology, 2015(11). (In Chinese).

[6] Xi Huang. How to conduct cultural transmission in college public English teaching $[\mathrm{J}]$. Heihe journal, 2013(12). (In Chinese).
[7] Qiong Pang . A new approach to analyze college public English teaching based on metacognitive theory [J]. Journal of kaifeng Education College, 2014(4). (In Chinese).

[8] Lulu Che . Application of structuralism theory in public English teaching in universities [J]. Journal of Chifeng College, 2013(02). (In Chinese).

[9] Bingfei Liu . Improving students' thinking abilities in comprehensive English class project---a perspective of "four resources models" [J]. Journal of Yichun university, 2015(5). (In Chinese).

[10] A Luke, P Freebody, Further notes on the four resources model [J]. Reading Online, 1999:1-4.

[11] KB Moni, The Four Resources Model in action: Practical would approaches to constructing a fancy from texts for primary and secondary classrooms. The Leading Literate mattress [J], 2001, 40 and 41.

[12] E Honan. Using the four resources model as a map of possible practices [J]. Text Next New Resources for Literacy Learning, 2004. 